\title{
Kewenangan dan Tanggung Jawab Hukum Pejabat Pembuat Akta Tanah Dalam Pelaksanaan Pendaftaran Hak Tanggungan Secara Elektronik
}

\author{
Shirley Zerlinda Anggraeni ${ }^{1}$, Marwanto ${ }^{2}$ \\ ${ }^{1}$ Program Studi Magister (S2) Kenotariatan, Fakutas Hukum Universitas Udayana, E-mail: \\ anggraenishirley@gmail.com \\ 2Fakutas Hukum Universitas Udayana, E-mail: marwanto@unud.ac.id
}

\begin{tabular}{l}
\hline Info Artikel \\
\hline Masuk: 4 Februari 2020 \\
Diterima: 9 Juli 2020 \\
Terbit: 31 Juli 2020 \\
Keywords: \\
Land Titles Registrar, \\
Registration, Electronic based \\
Mortgage Rights \\
\\
\\
Corresponding Author: \\
Shirley Zerlinda Anggraeni, \\
E-mail: \\
anggrenishirley@gmail.com \\
DOI : \\
10.24843/AC.2020.v05.i02.p05 \\
Tata kunci: \\
Tanggungan secara elektronik \\
\end{tabular}

\begin{abstract}
The legal issue in this study, is about the authority and responsibility of PPAT in registering mortgage rights electronically. This research is a normative legal research. The purpose of this study was to determine the authority and responsibility of PPAT in the electronic registration process of Mortgage related to the statement of accountability and the validity of electronic document. The results showed that PPAT has the authority to submit applications for registration of Mortgage Rights electronically at the Office of the Land Agency and a statement of accountability and validity of electronic document data is a condition for using the electronic based Mortgage Rights service system and is an integrated unit with the Regulation of the Minister of Agrarian Affairs and Spatial Planning / Head of the National Land Agency Number 9 of 2019 concerning Electronically Integrated Mortgage Services, the PPAT remains obligated to sign the statement letter. The results of the analysis, that if the electronic documents do not match the actual data, the registration will automatically be rejected by National Land Agency (BPN), as the registration application will not appear. The conclusion is that BPN will process the application electronically, only if the document attached is in accordance with the registration application physical data. Suggestion that can be given to PPAT is not to process registration of mortgage right if there is any mistake in the document required or if the documents are incomplete.
\end{abstract}

\begin{tabular}{l} 
Abstrak \\
\hline Isu hukum dalam penelitian ini, adalah tentang \\
kewenangan dan tanggung jawab PPAT dalam \\
mendaftarkan Hak Tanggungan secara elektronik. Jenis \\
penelitian yang dilakukan adalah penelitian hukum \\
normatif. Tujuan penelitian untuk mengetahui \\
kewenangan dan tanggung jawab PPAT dalam proses \\
pendaftaran Hak Tanggungan secara elektronik dikaitkan \\
dengan surat pernyataan pertanggungjawaban keabsahan \\
dan kebenaran data dokumen elektronik. Hasil penelitian \\
menunjukkan, bahwa PPAT berwenang mengajukan \\
permohonan pendaftaran Hak Tanggungan secara
\end{tabular}




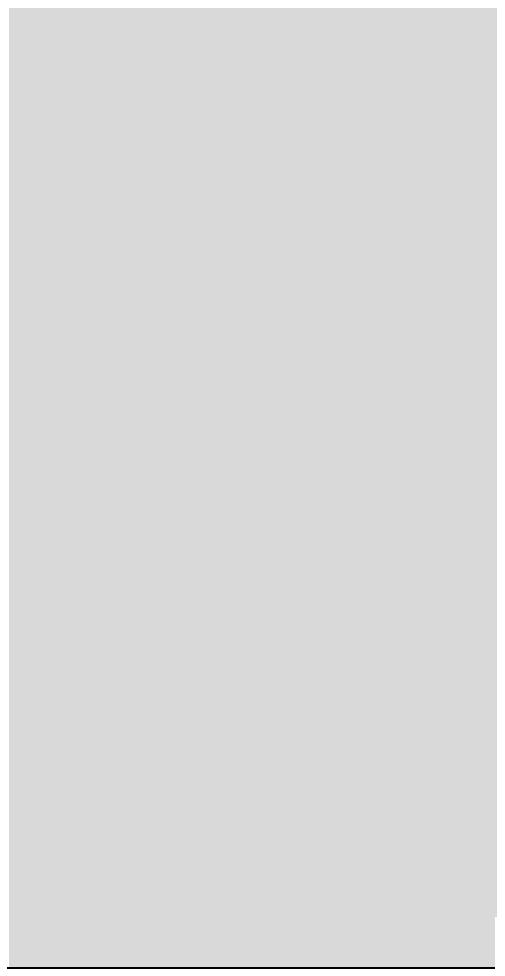

elektronik pada Kantor Badan Pertanahan dan surat pernyataan pertanggungjawaban keabsahan dan kebenaran data dokumen elektronik adalah syarat penggunaan sistem layanan Hak Tanggungan secara elektronik serta merupakan satu kesatuan dengan Peraturan Menteri Agraria dan Tata Ruang/Kepala Badan Pertanahan Nasional Nomor 9 Tahun 2019 tentang Pelayanan Hak Tanggungan Terintegrasi Secara Elektronik, maka PPAT tetap berkewajiban menandatangani surat pernyataan tersebut. Hasil analisis, bahwa apabila dokumen elektronik tersebut tidak sesuai dengan data yang sebenarnya, maka secara otomatis pendaftaran tersebut akan ditolak oleh Badan Pertanahan Nasional (BPN), karena aplikasi pendaftaran tidak akan muncul. Kesimpulannya adalah BPN akan memproses permohonan secara elektromnik, jika lampiran dokumen sudah sesuai dengan aplikasi pendaftaran. Saran yang dapat diberikan kepada PPAT adalah untuk tidak memproses pendaftaran hak tanggungan jika terdapat kesalahan persyaratan dokumen atau dokumen tidak lengkap.

\section{Pendahuluan}

Bertolak dari Peraturan Pemerintah Nomor 37 Tahun 1998 tentang Peraturan Jabatan Pejabat Pembuat Akta Tanah (selanjutnya disebut PP 37/1998), bahwa tugas pokok Pejabat Pembuat Akta Tanah (selanjutnya disebut PPAT) antara lain adalah membuat akta permohonan pendaftaran Hak Tanggungan. Pemberian Hak Tanggungan dapat diberikan atas suatu objek tanah berupa hak milik atas tanah, hak guna usaha, dan hak guna bangunan, serta hak pakai atas suatu tanah negara dimana dalam ketentuan yang berlaku, tanah tersebut wajib untuk didaftarkan serta memiliki sifat dapat dipindah tangankan. ${ }^{1}$ Selanjutnya untuk menjamin kepastian hukum, hak atas tanah sebagaimana tersebut di atas dapat dibebani dengan Hak Tanggungan, dengan cara Hak Tanggungan tersebut didaftarkan kepada Kantor Badan Pertanahan Nasional.

Berdasarkan Peraturan Menteri Agraria dan Tata Ruang/Kepala Badan Pertanahan Nasional Nomor 9 Tahun 2019 tentang Pelayanan Hak Tanggungan Terintegrasi Secara Elektronik (selanjutnya disebut Permen Agraria 9/2019), PPAT dapat mengajukan permohonan pendaftaran Hak Tanggungan secara elektronik. Ini berarti pendaftaran secara manual masih tetap diperbolehkan. Dalam artikel ini yang dibahas adalah permohonan pendaftaran Hak Tanggungan secara elektronik. Pasal 1 angka 6 Permen Agraria 9/2019, menentukan, bahwa pendaftaran Hak Tanggungan secara elektronik adalah: "serangkaian proses pelayanan Hak Tanggungan dalam rangka pemeliharaan data pendaftaran tanah yang diselenggarakan melalui sistem elektronik yang terintegrasi."

\footnotetext{
${ }^{1}$ Sari, S. N. I. \& Rizkianti, W. (2019). Studi Komparatif Pendaftaran Hak Tanggungan Di Kota Bogor Dan Depok. Universitas Pembangunan Nasional: Jurnal Yuridis, 2(6) 118-135.
} 
Diterbitkannya Permen Agraria 9/2019, merupakan suatu langkah inovatif terkait layanan pertanahan yang berbasis digital dalam hal memudahkan masyarakat untuk memperoleh pelayanan dari kementerian Agraria dan Tata Ruang/ Badan Pertanahan Nasioanal (selanjutnya disebut ATR/BPN). ${ }^{2}$ Terlebih, dalam era globalisasi seperti saat ini, mengandalkan perkembangan teknologi informasi di semua lini kehidupan masyarakat tidak dapat dihindari dan harus benar-benar dimanfaatkan secara optimal. Kehadiran sistem layanan Hak Tanggungan secara elektronik ini secara tidak langsung berdampak pada PPAT sebagai pejabat yang memiliki peran penting dalam proses pelaksanaan perjanjian, pemberian dan pendaftaran Hak Tanggungan. Sebagai pejabat yang berwenang melakukan pendaftaran Hak Tanggungan, PPAT bertanggung jawab dalam hal pembuatan akta sampai pada proses pendaftaran Hak Tanggungan di kantor Badan Pertanahan Nasional.

Keterlibatan PPAT secara langsung dalam proses pendaftaran Hak Tanggungan secara elektronik, sejatinya menimbulkan suatu tanggung jawab hukum terutama menyangkut tanggung jawab hukum atas berkas dan dokumen yang diunggah oleh PPAT pada saat menggunakan akun terdaftar dalam sistem layanan pendaftaran Hak Tanggungan secara elektronik. Khususnya dalam format Surat Pernyataan Pertanggungjawaban Keabsahan dan Kebenaran Data Dokumen Elektronik yang dalam redaksional alinea kedua mencantumkan frasa "Saya bertanggung jawab penuh atas keabsahan dan kebenaran isi dokumen secara formal maupun materiil."

Mengacu pada format Surat Pernyataan Pertanggungjawaban Keabsahan dan Kebenaran Data Dokumen Elektronik tersebut, didalamnya terdapat frasa "Saya bertanggung jawab penuh atas keabsahan dan kebenaran isi dokumen secara formal maupun materiil." Apakah yang dimaksud dengan frasa tersebut meliputi Akta Pemberian Hak Tanggungan (selanjutnya disebut APHT) yang merupakan akta partij dimana seharusnya pada akta partij PPAT bertanggung jawab secara formal? Berdasarkan uraian di atas, permasalahan yang dikaji dalam artikel ini adalah bagaimana kewenangan dan tanggung jawab PPAT dalam pelaksanaan pendaftaran Hak Tanggungan secara elektronik? Penulisan artikel ini bertujuan untuk menganalisa kewenangan dan tanggung jawab PPAT dalam pelaksanaan pendaftaran Hak Tanggungan secara elektronik, khususnya dikaitkan dengan surat pernyataan pertanggungjawaban keabsahan dan kebenaran data dokumen elektronik.

\section{Metode Penelitian}

Artikel ini merupakan jenis penelitian yuridis normatif yang mengkaji kewenangan dan tanggung jawab PPAT dalam pelaksanaan pendaftaran Hak Tanggungan secara elektronik. Hal ini dikaitkan dengan adanya kewajiban PPAT sebagai pejabat yang berwenang membuat permohonan pendaftaran Hak Tanggungan secara elektronik sebagaimana diatur dalam Pasal 9 ayat (3) Permen Agraria 9/2019.

Pendekatan yang digunakan untuk menjawab permasalahan dalam artikel ini adalah: (1) Pendekatan Undang-Undang (statutes approach), (2) Pendekatan konseptual (conceptual approach) serta (3) Pendekatan analisis (analytical approach). Artikel ini

\footnotetext{
2 Nadira, N. (2019). Pendaftaran Hak Tanggungan Elektronik Yang Akan Mulai Dilaksanakan Di Badan Pertanahan. Fairness and Justice: Jurnal Ilmiah Ilmu Hukum, 17(2), 162-165.
} 
menggunakan bahan hukum primer yaitu bahan hukum yang bersifat mengikat yang mencakup peraturan perundang-undangan yang terkait dengan permasalahan, dan bahan hukum sekunder, yang berupa bahan-bahan hukum yang menjelaskan lebih lanjut dan memberi keterangan mengenai bahan hukum primer. ${ }^{3}$ Literatur, berupa buku dan jurnal hukum dipergunakan sebagai bahan hukum sekunder. Artikel-artikel dari internet juga dipakai dalam penelitian ini sebagai bahan hukum tersier.

Teknik studi kepustakaan digunakan untuk mengumpulkan bahan hukum primer, sekunder dan tersier, dilanjutkan dengan sistem kartu (card system) untuk mencatat kutipan-kutipan dari pelaksanaan studi kepustakaan. Selanjutnya setelah bahan hukum tersebut terkumpul semua, maka disajikan secara deskriptif atau menggambarkan apa adanya terhadap suatu hal, ${ }^{4}$ dan dianalisis berdasarkan teori perrtanggungjawaban Fautes Personalles dan Fautes de Services serta peraturan perundang-undangan.

\section{Hasil dan Pembahasan}

\subsection{Kewenangan PPAT dalam Pelaksanaan Pendaftaran Hak Tanggungan Secara Elektronik}

Berdasarkan Pasal 2 ayat (1) PP 37/1998 tugas pokok PPAT adalah untuk membuat akta sebagai bukti telah dilakukanya perbuatan hukum tertentu mengenai hak atas tanah atau hak milik atas satuan rumah susun. Perbuatan hukum sebagaimana dimaksud dalam Pasal 2 ayat (1) tersebut ditentukan secara khusus pada Pasal 2 ayat (2) PP 37/1998. Kemudian Pasal 3 PP tersebut, menentukan: untuk melaksanakan tugas pokok sebagaimana dimaksud dalam pasal 2 seorang PPAT mempunyai kewenangan membuat akta otentik terkait dengan bidang pertanahan mengenai semua perbuatan hukum yang dimaksud dalam Pasal 2 ayat (2) terhadap hak atas tanah dan hak milik atas satuan rumah susun yang berada di dalam wilayah kerjanya.

PPAT berperan sangat penting dalam bidang pertanahan, salah satunya yang berhubungan dengan data yuridis dalam proses pencatatan tanah, termasuk perubahan atas data yuridis yang sudah tercatat sebelumnya. PPAT dapat dikatakan memiliki kewenangan yang cukup kompleks dalam bidang pertanahan, baik dari sisi tanah maupun pemegang hak. Kemampuan dan kecakapan PPAT akan sangat dibutuhkan dalam hal pembuatan akta tertentu dalam menjalankan wewenang PPAT. PPAT mendapatkan satu dari sekian kewenangan yaitu terkait dengan Hak Tanggungan. Secara umum Hak Tanggungan, memuat unsur- unsur pokok sebagai berikut:

1. Memberi kewenangan pada kreditur tertentu terhadap kreditur lainnya

2. Merupakan jaminan terhadap pelunasan hutang

3. Utang yang dijaminkan merupakan suatu utang tertentu.

4. Yang menjadi objek adalah hak atas tanah yang sesuai

\footnotetext{
${ }^{3}$ Sunggono, B., 2010. Metodelogi Penelitian Hukum. Rajawali Pers. Jakarta. hal. 114.

${ }^{4}$ Mezak, M. H. (2006). Jenis, Metode dan Pendekatan Dalam Penelitian Hukum. Law Review: Fakultas Hukum Universitas Harapan, 5(3).
} 
5. Dapat dibebankan atas tanahnya maupun pada benda-benda lain di atas tanah tersebut yang menjadi kesatuan dengan tanah yang dijaminkan.

Berdasarkan Undang-Undang Nomor 4 Tahun 1996 tentang Hak Tanggungan Atas Tanah Beserta Benda-Benda Yang Berkaitan Dengan Tanah (selanjutnya disebut UU Hak Tanggungan), pembebanan hak tanggungan dilaksanakan melalui dua tahap, yaitu pembuatan APHT dan dilanjutkan dengan pendaftaran oleh kantor Pertanahan. Pendaftaran ini adalah penting karena membuktikan saat lahirnya Hak Tanggungan yang dibebankan. ${ }^{5}$ Setelah APHT dibuat oleh PPAT, maka dalam waktu 7 (tujuh) hari kerja wajib didaftarkan lengkap dengan dokumen pendukungnya kepada Kantor Badan Pertanahan Nasional (selanjutnya disebut BPN) setempat yang merupakan lembaga tata usaha negara yang kewenangannya hanya menjalankan tugas terkait pertanahan di bidang pemerintahan. ${ }^{6}$ Kewajiban jangka waktu pendaftaran ini tercantum dalam Pasal 40 ayat (1) Peraturan Pemerintah Nomor 24 Tahun 1997 tentang Pendaftaran Tanah (selanjutnya disebut PP 24/1997) yang menentukan: Selambatlambatnya 7 (tujuh) hari kerja sejak tanggal ditandatanganinya akta yang bersangkutan, PPAT wajib menyampaikan akta yang dibuatnya berikut dokumendokumen yang bersangkutan kepada Kantor Pertanahan untuk didaftar.

Pendaftaran APHT disertai syarat-syarat administrasi lainnya ke Kantor BPN adalah hal yang bersifat wajib yang merupakan kewajiban PPAT. Apabila PPAT lalai dalam melakukan kewajiban tersebut dapat berakibat dikenakannya sanksi yang bersifat administratif yakni berupa teguran bahkan hingga yang lebih berat yakni diberhentikan dari jabatannya sebagai PPAT. Sementara itu, mengacu pada Pasal 9 Permen Agraria 9/2019, mekanisme pelayanan Hak Tanggungan yang terintegrasi secara elektronik diatur dalam prosedur sebagai berikut:

1. Permohonan layanan Hak Tanggungan secara elektronik diajukan oleh pengguna terdaftar melalui sistem yang disiapkan kementerian serta dilengkapi persyaratan permohonan sesuai dengan ketentuan peraturan perundang-undangan.

2. Pemohon harus membuat surat pernyataan mengenai pertanggungjawaban keabsahan dan kebenaran data Dokumen Elektronik yang diajukan yang dibuat dalam bentuk Dokumen Elektronik. Adapun dokumen elektronik tersebut meliputi: Kartu Tanda Penduduk (KTP) Debitur, Kartu Keluarga (KK) Debitur, Kartu Tanda Penduduk (KTP) Pemberi Persetujuan, Kartu Keluarga (KK) Pemberi Persetujuan, Kartu Tanda Penduduk (KTP) Saksi-Saksi, Surat Kuasa membebankan Hak Tanggungan (SKMHT), Akta Pemberian Hak Tanggungan (APHT), Perjanjian Kredit, Sertipikat Hak Atas Tanah, dan Foto copy Pajak Bumi dan Bangunan.

3. Khusus mengenai syarat Sertipikat Hak Atas Tanah atau Hak Milik Atas Satuan Rumah Susun, nama yang tercantum di sertipikat harus nama debitur.

4. Sistem selanjutnya akan menerbitkan tanda bukti daftar seletah permohonan layanan telah diterima oleh Sistem Hak Tanggungan secara elektronik. Bukti pendaftataran permohonan dimaksud paling sedikit memuat antara lain nomor

\footnotetext{
${ }^{5}$ Nufus, N. H. (2010). Proses Pembebanan Hak Tanggungan terhadap Tanah yang Belum Bersertifikat. Universitas Diponegoro Semarang. hal. 24

6 Sutedi, A., 2012. Hukum Hak Tanggungan. Jakarta: Sinar Grafika. hal. 161.
} 
berkas dan tanggal pendaftaran; juga nama orang yang melakukan permohonan; dan kode pembayaran biaya layanan.

5. Setelah biaya pendaftaran dan juga data permohonan terkonfirmasi oleh sistem elektronik barulah permohonan diproses. Selanjutnya Sistem Hak Tanggungan secara elektronik akan menerbitkan hasil layanan hak tanggungan berupa Sertipikat Hak Tanggungan; dan catatan hak tanggungan pada buku tanah dan Sertipikat Hak Atas Tanah atau Hak Milik Atas Satuan Rumah Susun.

Asas publisitas artinya adalah pendaftaran dan pencatatan dari pembebanan objek Hak Tanggungan sehingga terbuka dan dapat dibaca dan diketahui umum. Asas tersebut tertuang dalam Pasal 13 UU Hak Tanggungan, dan diimplementasikan dengan dilakukannya proses pendaftaran Hak Tanggungan ke kantor Agraria dan Tata Ruang/ Badan Pertanahan Nasioanal (selanjutnya disebut ATR/BPN). Selain itu, syarat mutlak untuk lahirnya Hak Tanggungan itu sendiri adalah dengan didaftarkannya pemberian Hak Tanggungan di kantor ATR/BPN, yang kemudian diwujudkan pembuatan Sertipikat Hak Tanggungan serta dicantumkan pula pembebanan Hak Tanggungan tersebut pada sertipikat tanah yang bersangkutan. Selanjutnya menurut Pasal 13 Permen Agraria 9/2019 pencatatan Hak Tanggungan pada buku tanah yang bersangkutan dilakukan oleh Kepala Kantor Pertanahan, sementara pencatatan Hak Tanggungan pada Sertipikat Hak Atas Tanah atau Hak Milik Satuan Rumah Susun dapat dilakukan oleh Kreditor dengan mencetak catatan yang diterbitkan oleh Sistem Hak Tanggungan secara elektronik dan melekatkannya pada Sertipikat Hak atas Tanah atau Hak Milik Satuan Rumah Susun serta menjadi satu kesatuan dengan Sertipikat Hak Tanggungan.

Berdasarkan pembahasan di atas, dapat dikatakan bahwa saat pendaftaran Hak Tanggungan pada kantor ATR/BPN, merupakan awal penerima Hak Tanggungan mendapat kewenangan atas objek Hak Tanggungan untuk melakukan perbuatan hukum terhadapnya. Perbuatan hukum yang dimaksud hanyalah jika pemberi Hak Tanggungan (Debitur) cidera janji, sesuai dengan hak Pemegang Hak Tanggungan bedasarkan Pasal 6 UU Hak Tanggungan. Pasal 6 UU Hak Tanggungan, menentukan: “apabila Debitur cidera janji, pemegang Hak Tanggungan pertama mempunyai hak untuk menjual obyek Hak Tanggungan atas kekuasaan sendiri melalui pelelangan umum serta mengambil pelunasan piutangnya dari hasil penjualan tersebut."

Proses pendaftaran Hak Tanggungan adalah hal yang sangat penting bagi para pemegang/penerima Hak Tanggungan karena proses pendaftaran tersebut memberikan jaminan kepastian hukum terhadap pemberi dan penerima Hak Tanggungan dengan didaftarkan Hak Tanggungan di kantor ATR/BPN. Selain itu, pendaftaran Hak Tanggungan juga akan memberi perlindungan hukum, khususnya ketika pihak debitur melakukan tindakan yang dapat merugikan pihak lainnya dalam hal ini adalah wanprestasi (cidera janji). Dalam konteks pendaftaran Hak Tanggungan secara elektronik, peran dan wewenang PPAT menjadi sangat krusial terhadap kuatnya (secara hukum) kedudukan pemegang Hak Tanggungan.

Walaupun tidak dijelaskan secara eksplisit pada Pasal 7 ayat 1 Permen Agraria 9/2019 bahwa PPAT sebagai salah satu pengguna layanan Hak Tanggungan secara elektronik, namun kewenangan PPAT dalam pelaksanaan pendaftaran Hak Tanggungan secara elektronik jelas disebutkan dalam Pasal 10 yaitu "PPAT berwenang menyampaikan permohonan pendaftaran hak tanggungan dengan salah 
satu persyaratan adalah APHT yang disampaikan dalam bentuk dokumen elektronik". Sebagai pihak yang berwenang menjalankan proses pendaftaran layanan Hak Tanggungan secara elektronik, PPAT diwajibkan terdaftar dalam Aplikasi Mitra Kerja yaitu aplikasi yang digunakan oleh Kementerian Agraria dan Tata Ruang/BPN dengan PPAT sebagai mitra kerjanya. Selain itu, sistem administrasi dan manajemen Kantor PPAT juga harus melakukan kesiapan dengan dukungan sarana yang memadai seperti scanner, jaringan internet maupun komputer. ${ }^{7}$ Sebelum diberlakukannya kebijakan terkait pendaftaran Hak Tanggungan secara elektronik, selama ini pendaftaran Hak Tanggungan dijalankan secara manual dengan cara dicatat terlebih dahulu oleh PPAT pada portal/website resmi dari Kementerian Agraria dan Tata Ruang/BPN dan dilanjutkan dengan menyerahkan berbagai persyaratan administratif kepada Kantor ATR/BPN. Terkait dengan permohonan pendaftaran dan penyampaian APHT diportal kementerian tersebut dapat dilakukan oleh PPAT atau oleh orang yang diberikan kuasa.

Pasal 3 ayat (2) Permen Agraria No 9/2019 menjelaskan bahwa "pelayanan pendaftaran Hak Tanggungan "dapat" dilaksanakan secara elektronik melalui Sistem Hak Tanggungan secara elektronik." Kata "dapat" di sini bisa dianggap memiliki pengertian adanya pilihan menggunakan Sistem Hak Tanggungan secara elektronik maupun secara manual seperti sebelumnya untuk mendapatkan pelayanan Hak Tanggungan. Pengertian Pasal 3 tersebut di atas memberikan kemudahan bagi PPAT untuk dapat memilih apakah akan menggunakan sistem pendaftaran elektronik atau secara manual. Hal ini terkait dengan kewenangan PPAT khususnya dalam pendaftaran Hak Tanggungan secara elektronik dengan adanya ketentuan Permen Agraria 9/2019 yang bersifat khusus lainnya, antara lain Pasal 9 ayat (5) yang menjelaskan bahwa harus debitur sendiri selaku pihak yang memberi Hak Tanggungan. Pasal 9 ayat (5) ini berakibat pada tidak dapat digunakaanya layanan Hak Tanggungan secara elektronik, saat dimana yang memberi Hak Tanggungan bukanlah debitur sendiri. Meskipun demikian, apa yang diatur dalam Pasal 9 ayat (5) tidak melarang adanya pemberian Hak Tanggungan oleh pemilik jaminan yang adalah pihak lain yang bukan debitur, sehingga PPAT tetap dapat memproses APHT namun hanya mendaftarkannya secara manual. Hal ini menandakan bahwa layanan Hak Tanggungan secara elektronik bukanlah merupakan suatu kewajiban, melainkan hanya alternatif untuk memudahkan proses pendaftaran. Hanya saja, terkait dengan kewenangan PPAT, akan menjadi permasalahan apabila layanan Hak Tanggungan secara manual dihilangkan setelah diberlakukannya Hak Tanggungan secara elektronik oleh Kantor Badan Pertanahan Nasional, dimana hal tersebut dapat diartikan sebagai suatu larangan untuk mendaftarkan Hak Tanggungan apabila objek Hak Tanggungan bukan atas nama debitur.

\subsubsection{Tanggung Jawab Hukum PPAT dalam Proses Pendaftaran Hak Tanggungan Secara Elektronik}

Kamus Besar Bahasa Indonesia (KBBI) memuat bahwa pengertian tanggung jawab adalah kewajiban untuk menanggung segala sesuatunya bila terjadi apa-apa

\footnotetext{
7 Yubaidi, R.S. (2019). Faktor Kesiapan PPAT dalam Pelaksanaan Pendaftaran Hak Tanggungan Terintegrasi Secara Elektronik. Universiti Kebangsaan Malaysia.
} 
boleh dituntut, dipersalahkan, dan diperkarakan. ${ }^{8}$ Dari pengertian tersebut, dapat ditafsirkan bahwa pertanggungjawaban harus memiliki dasar, yakni hal yang membuat timbulnya hak bagi seseorang untuk melakukan tuntutan sekaligus memberi kewajiban bagi orang lain untuk melakukan pertanggungjawaban. ${ }^{9}$

Suatu kewenangan terutama bagi pejabat publik, memiliki kaitan yang sangat erat dengan tanggung jawab dan kewajiban. Menurut Kranenburg dan Vegtig "dalam hal pertanggungjawaban oleh seorang pejabat, terdapat dua teori terkait. Teori pertama adalah bahwa apabila terjadi kerugian pada pihak ketiga, maka pejabat berwenang wajib dibebankan atas tidakannya yang telah menimbulkan kerugian tersebut. Teori ini disebut Fautes Personalles. Sementara itu, teori yang kedua adalah dimana apabila terjadi kerugian pada pihak ketiga, maka akan dibebankan kepada instansi. Teori ini dinamakan Teori Fautes de Services, dan secara khusus teori ini menekankan bahwa tanggung jawab yang dimaksud, dibebankan pada jabatan."10 Teori pertanggungjawaban ini digunakan untuk menganalisis tanggung jawab PPAT, khususnya dalam kewenangannya terkait proses pendaftaran Hak Tanggungan secara elektronik, baik pertanggungjawaban secara formal maupun pidana.

Peraturan perundang-undangan yang mengatur PPAT menegaskan bahwa pertanggungjawaban yang dimiliki oleh PPAT tidak hanya terkait dengan pembuatan akta tapi juga pertanggungjawaban setelah akta ditandatangani. Sebagai sebuah profesi, tanggung jawab PPAT dapat dibagi menjadi dua, yaitu pertanggungjawaban etik, dalam kaitan dengan profesi PPAT serta tanggung jawab hukum, dalam kaitannya dengan akta yang dibuat, yang kemudian dapat dijabarkan lagi berdasarkan hukum administrasi, hukum perdata dan hukum pidana. ${ }^{11}$

Menurut Kitab Undang-Undang Hukum Perdata (selanjutnya disebut KUH Perdata), seorang PPAT apabila melakukan perbuatan melawan hukum sebagaimana diatur dalam KUH Perdata Pasal 1365 dapat dikenakan pertanggungjawaban perdata. Bentuk pertanggungjawaban perdata yang dimaksud adalah karena sebuah kesalahan, dimana seorang PPAT menimbulkan kerugian terhadap pihak ketiga, terlebih lagi hal itu dilakukan secara sengaja serta diperkirakan oleh PPAT itu sendiri. Dalam hal ini, PPAT memiliki kewajiban untuk memberikan ganti rugi atas kesalahan yang sudah diperbuat. Hal tersebut juga mengacu pada Pasal 55 Peraturan Kepala BPN Nomor 1 Tahun 2006, tentang Ketentuan Pelaksanaan Peraturan Pemerintah Nomor 37 Tahun 1998 tentang Peraturan Jabatan Pejabat Pembuat Aka Tanah. Dalam hal pelaksanaan pembuatan akta di bidang pertanahan, PPAT memiliki pertanggungjawaban dengan berdasarkan kesalahan, yang artinya bahwa PPAT bertanggung jawab atas

8 http://kbbi.web.id/tanggung\%20jawab, diakses pada hari Selasa, 7 Januari pukul 12.59 WITA.

${ }^{9}$ Nugraheni. L.A. (2017). Tanggung Jawab Hukum Notaris Dalam Pendaftaran Jaminan Fidusia Secara Elektronik (Online System). Jurnal Hukum Universitas Atma Jaya.

${ }^{10}$ Rismayanthi, I. A. W. (2016) Tanggung Jawab Pejabat Pembuat Akta Tanah (PPAT) Terhadap Pendaftaran Peralihan Hak Atas Tanah Yang Menjadi Objek Sengketa. Acta Comitas: Jurnal Hukum Kenotariatan, 1(1), 77-93.

${ }^{11}$ Agustina, A., \& Tanawijaya, H. (2016). Tanggung Jawab Pejabat Pembuat Akta Tanah (PPAT) Dalam Penandatanganan Akta Jual Beli Yang Didasari Atas Blangko Kosong. Jurnal Hukum Adigama. 1(2). 
pelanggaran yang dilakukan dikarenakan suatu kesengajaan dan telah diperkirakan sebelumnya dan menimbulkan kerugian. ${ }^{12}$

PPAT dalam kewenangannya sebagai seorang pejabat umum adalah menjamin kebenaran perbuatan hukumnya, serta kebenaran formal dalam setiap akta otentik yang dbuatnya. PPAT juga memiliki peran dalam hal memeriksa semua kewajiban terkait dengan akta yang akan dibuat khususnya yang bersifat administratif yang harus dipenuhi oleh para pihak. Seperti diutarakan sebelumnya, bentuk pertanggungjawaban PPAT dalam kaitan dengan profesinya menganut prinsip tanggung jawab berdasarkan kesalahan, maka dari itu, PPAT wajib bertanggungjawab apabila terjadi kesalahan terhadap akta yang dibuat. Apabila unsur pelanggaran yang dimaksud bersumber dari para pihak, maka PPAT tidak dapat dimintakankan pertanggungjawaban. Pertanggungjawaban PPAT terhadap akta yang telah dibuat, yang mana terbukti mengandung keterangan palsu, tidak dapat dipertanggungjawabkan secara hukum terhadap PPAT sebagai pembuat akta, dikarenakan PPAT hanya mencatat atau menuangkan suatu perbuatan hukum yang dilakukan oleh para pihak/penghadap ke dalam akta. Keterangan palsu yang disampaikan oleh para pihak adalah merupakan tanggung jawab dari pihak yang bersangkutan. ${ }^{13}$

Secara khusus, PPAT hanya menyesuaikan syarat-syarat formal dari penyampaian para pihak lalu dituangkan dalam suatu bentuk akta. PPAT tidak memiliki kewajiban ataupun kewenangan untuk menelisik kebenaran materiil dari isi akta yang dibuatnya. Sementara itu, frasa yang tercantum dalam "Surat Pernyataan Pertanggungjawaban Keabsahan dan Kebenaran Data Dokumen Elektronik" dalam proses pendaftaran Hak Tanggungan secara elektronik, yang dalam redaksional alinea kedua mencantumkan frasa "...saya bertanggung jawab penuh atas keabsahan dan kebenaran isi dokumen secara formal maupun materiil." Kalimat tersebut dapat memberi tanggung jawab hukum tersendiri bagi PPAT sebagai pihak yang terlibat langsung dalam proses pendaftaran Hak Tanggungan secara elektronik, terutama sepanjang mengenai pertanggungjawaban secara materiil. Sebagaimana ajaran hukum menyatakan bahwa kebenaran materiil adalah kebenaran sejati atau kebenaran yang sesungguhnya, yang dimana hal tersebut merupakan domain hukum pidana, sedangkan Notaris/PPAT berada dalam domain hukum Perdata yang hanya bertanggung jawab terbatas pada kebenaran formal.

Dalam Permen Agraria No 9/2019, khususnya dalam Pasal 9 ayat (3) juga tidak diatur pernyataan pertanggungjawaban keabsahan dan kebenaran secara materiil. Pasal 9 ayat (3) hanya menyebutkan bahwa: "Selain persyaratan sebagaimana dimaksud pada ayat (2) pemohon membuat Surat Pernyataan mengenai pertanggungjawaban keabsahan dan kebenaran data Dokumen Elektronik yang diajukan." Selain itu, keberadaan APHT yang yang merupakan akta autentik, kekuatan pembuktiannya adalah sempurna termasuk dengan tanda tangan yang ada di dalamnya. Tanpa adanya surat pernyataan yang dimaksud, pada PPAT selaku pejabat umum sudah melekat tanggung jawab yang dipergunakan sebagai bukti sempurna yang diakui secara formal. Terkait dengan hal itu, apabila PPAT tersebut telah

${ }^{12}$ Ibid

${ }^{13}$ Mamminanga, A., (2008) Pelaksanaan Kewenangan Majelis Pengawas Notaris Daerah dalam Pelaksanaan Tugas Jabatan Notaris berdasarkan UUJN, Tesis, Fakultas Hukum Universitas Gajah Mada, Yogyakarta, hal. 32. 
melaksanakan tugas sesuai prosedur seperti yang diatur dalam peraturan Perundangundangan, maka PPAT tidak dapat diminta bertanggungjawab secara pidana atas akta yang dibuatnya ${ }^{14}$, khususnya yang terkait dengan PPAT, PJPPAT, Kode etik PPAT, dan PerkaBPN.

Keberadaan surat pernyataan pertanggungjawaban keabhsaan dan kebenaran data dokumen elektronik yang formatnya ditetapkan secara baku dan merupakan satu kesatuan dengan Permen Agraria 9/2019, mengakibatkan ada kewajiban bagi PPAT untuk tetap menandatangani surat pernyataan tersebut. Penandatanganan surat pernyataan tersebut dapat diartikan PPAT bertanggungjawab terhadap kebenaran dari dokumen yang dilampirkan adalah sesuai dengan dokumen fisik yang ada pada PPAT dan merupakan kelengkapan syarat yang harus dipenuhi dalam permohonan pendaftaran Hak Tanggungan secara elektronik. Bila tidak terpenuhinya syarat tersebut akan berakibat permohonan pendaftaran tersebut tidak dapat diajukan untuk diproses, dan akibatnya adalah Sertipikat Hak Tanggungan tidak dapat diterbitkan.

Pasal 20 ayat 2 Permen Agraria 9/ 2019 memuat bahwa pertanggungjawaban terkait kebenaran materiil suatu dokumen yang diunggah dalam layanan pendaftaran Hak Tanggungan secara elektronik bukan menjadi domain Kantor Pertanahan. Hal tersebut sejatinya sejalan dengan pertanggungjawaban PPAT yang tidak dapat dimintakan pertanggungjawaban terhadap isi dan materi dari akta tersebut namun hanya bertanggungjawab secara formal terhadap akta yang dibuatnya, terkecuali pada relaas akta itu sendiri. ${ }^{15}$

\section{Kesimpulan}

Berdasarkan pembahasan sebagaimana telah diuraikan di atas, maka dapat disimpulkan bahwa kewenangan PPAT sebagai pejabat yang berwenang untuk mendaftarkan Hak Tanggungan secara elektronik sebagaimana diatur dalam Pasal 10 Permen Araria 9/2019 adalah untuk mengunggah persyaratan permohonan dalam bentuk dokumen elektronik yang terdiri dari Kartu Tanda Penduduk (KTP) Debitur, Kartu Keluarga (KK) Debitur, Kartu Tanda Penduduk (KTP) Pemberi Persetujuan, Kartu Keluarga (KK) Pemberi Persetujuan, Kartu Tanda Penduduk (KTP) Saksi-Saksi, Surat Kuasa membebankan Hak Tanggungan (SKMHT), Akta Pemberian Hak Tanggungan (APHT), Perjanjian Kredit, Sertipikat Hak Atas Tanah, dan Foto copy Pajak Bumi dan Bangunan. Mengenai kewenangan khusus PPAT diatur dalam Pasal 9 ayat (5) Permen Agraria 9/2019 dimana untuk menggunakan layanan sistem Hak Tanggunga secara ekektronik, PPAT hanya berwenang mendaftarkan Pemberian Hak Tanggungan oleh pemberi Hak Tanggungan yang merupakan debitur sendiri (bukan atas nama orang lain), sehingga apabila pemberi Hak Tanggungan adalah pihak ketiga (bukan debitur sendiri) maka pendaftaran Hak Tanggungan dilakukan secara manual tanpa menggunakan layanan sistem Hak Tanggungan secara elektronik.

\footnotetext{
${ }^{14}$ Aditama, P. N. (2018). Tanggung Jawab Pejabat Pembuat Akta Tanah Dalam Memberikan Perlindungan Hukum Bagi Para Pihak Pada Peralihan Hak Atas Tanah Melalui Jual Beli. Lex Renasissance, 1(3), 189-205.

15Jaya, W. P. (2017). Pertanggung Jawaban Notaris Berkenaan Dengan Kebenaran Substansi Akta Otentik. Rechtidee, 12(2), 267-285.
} 
Mengenai tanggung jawab PPAT dalam pendaftaran Hak Tanggungan secara elektronik adalah PPAT harus memeriksa kelengkapan dan kebenaran seluruh dokumen elektorik sebelum melakukan proses pendaftaran Hak Tanggungan secara elektronik. Apabila ternyata kemudian terdapat kesalahan pada dokumen elektornik yang dilampirkan maka proses pendaftaran Hak Tanggungan secara elektronik tersebut akan ditolak oleh sistem.

Sehubungan dengan kesimpulan tersebut di atas, dapat disarankan kepada PPAT untuk menjalankan kewenangannya mendaftarkan Hak Tanggungan secara elektronik sesuai Permen Agraria 9/2019 dan bila terdapat keraguan terdahap data elektronik yang diberikan debitur sebaiknya tidak diproses lebih lanjut oleh PPAT. Disarankan juga kepada debitur untuk memberikan data yang benar kepada PPAT untuk digunakan dalam pendaftaran Hak Tanggungan secara elektronik karena kesalahan data akan menghambat proses pendaftaran tersebut.

\section{Daftar Pustaka}

\section{Buku:}

Sunggono, B. (2010). Metodelogi Penelitian Hukum. Jakarta : Rajawali Pers

Sutedi, A. (2012). Hukum Hak Tanggungan. Jakarta: Sinar Grafika.

\section{Jurnal:}

Aditama, P.N. (2018). Tanggung Jawab Pejabat Pembuat Akta Tanah Dalam Memberikan Perlindungan Hukum Bagi Para Pihak Pada Peralihan Hak Atas Tanah Melalui Jual Beli. Lex Renasissance, 1(3), 118-205.

Agustina, A., \& Tanawijaya, H. (2016) Tanggung Jawab Pejabat Pembuat Akta Tanah (PPAT) Dalam Penandatanganan Akta Jual Beli Yang Didasari Atas Blangko Kosong. Jurnal Hukum Adigama, 1(2).

Din, T., Mulyadi, L., Narsudin, U. (2016). Perlindungan Hukum Terhadap Pejabat Pembuat Akta Tanah Dalam Pembuatan Akta Otentik. Jurnal Penelitian Hukum: Legalitas, 2(10).

Jaya, W. P. (2017). Pertanggung Jawaban Notaris Berkenaan Dengan Kebenaran Substansi Akta Otentik. Rechtidee, 12(2), 267-285.

Mezak, M. H. (2006). Jenis, Metode dan Pendekatan Dalam Penelitian Hukum. Law Review: Fakultas Hukum Universitas Harapan, 5(3).

Nadira, N. (2019). Pendaftaran Hak Tanggungan Elektronik Yang Akan Mulai Dilaksanakan Di Badan Pertanahan. Fairness and Justice: Jurnal Ilmiah Ilmu Hukum, 17(2), 162-165.

Nugraheni. L. A. (2017). Tanggung Jawab Hukum Notaris Dalam Pendaftaran Jaminan Fidusia Secara Elektronik. Jurnal Hukum Universitas Atma Jaya, Yogyakarta.

Rismayanthi, I. A. W. (2016). Tanggung Jawab Pejabat Pembuat Akta Tanah (PPAT) Terhadap Pendaftaran Peralihan Hak Atas Tanah Yang Menjadi Objek Sengketa. Acta Comitas: Jurnal Hukum Kenotariatan, 1(1).

Sari, S. N. I. \& Rizkianti, W. (2019). Studi Komparatif Pendaftaran Hak Tanggungan Di Kota Bogor Dan Depok. Universitas Pembangunan Nasional: Jurnal Yuridis, 2(6). 118-135. 
Yubaidi, R.S. (2019). Faktor Kesiapan PPAT dalam Pelaksanaan Pendaftaran Hak Tanggungan Terintegrasi Secara Elektronik. Universiti Kebangsaan Malaysia.

\section{Tesis atau Disertasi:}

Mamminanga, A., (2008) Pelaksanaan Kewenangan Majelis Pengawas Notaris Daerah dalam Pelaksanaan Tugas Jabatan Notaris berdasarkan UUJN, Tesis, Fakultas Hukum Universitas Gajah Mada, Yogyakarta.

Nufus, N. H. (2010). Proses Pembebanan Hak Tanggungan terhadap Tanah yang Belum Bersertifikat. Universitas Diponegoro Semarang.

\section{Online/World Wide Web:}

Kamus Besar Bahasa Indonesia (2019) http:/ / kbbi.web.id/tanggung\%20jawab, diakses pada hari Selasa, 7 Januari pukul 12.59 WITA.

Kementrian Agraria dan Tata Ruang/ Badan Pertanahan Nasional. Pendaftaran Hak Tanggungan.https://www.atrbpn.go.id/Publikasi/StandarProsedur/moduleI d/122856/itemName/Pendaftaran_Hak_Tanggungan/controller/Item/action /Detail. Diakses 7 Januari pukul 14.34 Wita. 